\title{
Faktor Bauran Pemasaran Yang Mempengaruhi Konsumen Terhadap Keputusan Pembelian Produk Pada Konsumen Starbucks Coffee
}

\author{
Arief Satriansyah \\ Universitas Bina Sarana Informatika Jakarta \\ E-mail: arief.aie@bsi.ac.id
}

Cara Sitasi: Satriansyah, A. (2019). Faktor Bauran Pemasaran Yang Mempengaruhi Konsumen Terhadap Keputusan Pembelian Produk Pada Konsumen Starbucks Coffee. Widya Cipta, 3(1), 157-164

\begin{abstract}
This research was conducted to find out how much influence of the product, price, place and promotion on Starbucks Coffee Bogor city consumers' decision making. The research used the survey method with a sample of 100 people. The sampling technique is non-probability sampling: judgment sampling. The analytical method used is the method of correlation analysis and multiple regression. The results of the study show that both partially and jointly the factors of product, price, place, and promotion have a significant influence on product purchase decision making. The higher the level of influence of the product, price, place and promotion, the stronger the influence of product purchasing decisions. Based on the results of the analysis of the factors that influence the purchasing decision shows the adjusted $R 2$ value of 0.663 , this means that all variables derived from the marketing mix have a joint contribution of $66.3 \%$ to the dependent variable $(Y)$, namely the purchasing decision. The remaining $33.7 \%$ is influenced by other factors.
\end{abstract}

Keywords:marketing mix, decision making, Starbuck Coffee

\section{PENDAHULUAN}

Perusahaaan sebagai salah satu lembaga ekonomi dituntutmempunyai peran serta secara aktif di dalam pembangunan suatu negara. Melalui aktivitas ekonomi, perusahaan dapat memberikan pelayanan dalam memenuhi kebutuhan masyarakat yang beraneka ragam, baik kebutuhan akan pelayanan jasa maupun kebutuhan akan barang. Bagi perusahaan yang menghasilkan produk, tak pelak lagi produk tersebut memegang peranan penting jika dikaitkan dengan tujuan perusahaan.

Pada dasarnya perusahaan mengarahkan tujuannya untuk memperoleh keuntungan yang optimal dan menjalankan operasi perusahaan secara kontinyu. Untuk memperoleh keuntungan dari setiap aktivitas yang dilakukan perusahaan, maka perusahaan melakukan berbagai usaha dan strategi segmentasi pasar. Usaha yang dilakukan perusahaan antara lain menekan biaya produk dan biaya pemasaran, memproduksi produk-produk yang banyak diminati konsumen, meningkatkan mutu produk, menjual produk dengan harga yang terjangkau, pemberian pelayanan yang baik, dan sebagainya.

Persaingan yang semakin tinggi menuntut adanya keunggulan bersaing yang harus dimiliki oleh setiap perusahaan dan membutuhkan strategi pemasaran yang tepat. Suatu perencanaan strategi pemasaran tidak lepas dari sisi konsumen, sebab konsumen mempunyai peranan penting, dimana konsumen sebagai alat ukur dalam menentukan suatu barang atau jasa (Lilik Suprapti, 2010: 1).

Jumlah pesaing yang semakin banyak membuat pelanggan memiliki pilihan yang banyak pula untuk mendapatkan produk yang sesuai dengan harapannya. Sehingga akibat dari kondisi tersebut pelanggan menjadi lebih cermat dan pintar menghadapi setiap produk yang diluncurkan. Salah satu cara agar pelanggan tetap memilih produk tertentu adalah dengan membuat perbedaan antara produknya dengan produk sejenis atau yang menjadi penggantinya. Hermawan Kartajaya mengatakan, "It's better to be a little bit diferent than to be a little bit better". Menurut Hermawan, akan lebih baik sebuah produk menawarkan hal yang berbeda dari produk lainnya, daripada menawarkan hal serupa namun lebih baik dari pesaingnya. Hermawan Kartajaya (2008:133)

Kegiatan pemasaran menjadi tolak ukur suatu perusahaan dalam proses penyampaian produk kepada pelanggan serta pencapaian tujuan perusahaan berupa penjualan produk yang optimal. Sebelum meluncurkan produknya perusahaan harus mampu melihat atau mengetahui apa yang dibutuhkan oleh konsumen. Sehingga sudah sewajarnya jika segala kegiatan perusahaan harus selalu dicurahkan untuk memenuhi kebutuhan konsumen dan kemudian konsumen akan memutuskan membeli produk tersebut. Dan pada 
akhirnya tujuan perusahaan yaitu memperoleh laba akan tercapai.

Untuk memenangkan persaingan usaha, perlu adanaya strategi pemasaran yang efektif, salah satunya adalah melihat dari sisi faktor pemasaran, dalam hal ini adalah bauran pemasaran, tidak hanya sebatas menyusun bauran pemasaran sebagai taktik namun lebih dari itu juga menyusun strategi yaitu bagaimanamendapatkanpasar yang dituju, serta posisi produk yang diinginkan oleh perusahaan di dalam benak hati konsumen. Inti dari setiap strategi pemasaran yang baik adalah suatu strategi pencapaian posisi produk secara tepat.

Dalam hal ini yang artinya bauran pemasaran adalah sekumpulan alat pemasaran (marketing mix) yang dapat digunakan oleh perusahaan untuk mencapai tujuan pemasaran dalam pasar sasaran. Bauran pemasaran terdiri atas segala sesuatu yang dapat dilakukan perusahaan untuk mempengaruhi permintaan produknya". Kemungkinankemungkinan itu dapat dikelompokkan menjadi empat kelompok variabel yang dikenal dengan $4 \mathrm{P}$ yaitu, produk, harga, lokasi, dan promosi. Kotler \& Amstrong (2006: 72)

Konsumen merupakan semua individu dan rumah tangga yang membeli atau memperoleh barang atau jasa untuk dikonsumsi pribadi. Kotler (2000)

Konsumen sebagai individu dalam mendapatkan atau membeli barang telah melalui proses-proses atau tahapan-tahapan terlebih dahulu seperti mendapat informasi baik melalui iklan atau referensi dari orang lain kemudian membandingkan produk satu dengan produk lain sampai akhirnya pada keputusan membeli produk tersebut. Para pemasar harus memahami setiap sisi perilaku konsumen. Perusahaan yang cerdas akan mencoba memahami sepenuhnya proses pengambilan keputusan pelanggan yaitu semua pengalaman mereka dalam belajar, memilih, menggunakan, bahkan dalam mendisposisikan suatu produk (Kotler, 2007:234).

Keputusan untuk membeli yang diambil oleh pembeli sebenarnya merupakan kumpulan dari sejumlah keputusan. Keputusan pembelian merupakan keputusan konsumen untuk membeli suatu produk setelah sebelumnya memikirkan tentang layak tidaknya membeli produk itu dengan mempertimbangkan informasi - informasi yang ia ketahui dengan realitas tentang produk itu setelah ia menyaksikannya.Kotler dalam Lilik (2010: 43)

Istilah pengaruh pengambilan keputusan untuk membeli produk mengandung arti bagaimana suatu produk didefinisikan oleh konsumen melalui pengaruh - pengaruh pentingnya dibenak hati konsumen yang dimiliki oleh produk tersebut.
Kopi merupakan salah satu minuman untuk memenuhi kebutuhan sekunder bagi manusia. Kopi merupakan minuman yang diracik dari biji tanaman kopi, yang menjadi minuman para masyarakat dari kalangan bawah sampai kalangan atas. Hingga saat ini hampir seluruh ornag didunia menyukai kopi sebagai minuman pada pagi hari atau pada saat senggang. Banyak perusahaan yang berlomba-lomba untuk membuka kedai kopi yang menarik perhatian para pelanggannya dari kopi instant hingga kopi yang langsung diracik dari biji kopinya.

Starbucks Coffee Company adalah salah satu pengecer, pemanggang terkemuka dan merek khusus kopi di dunia. Hal ini berkomitmen untuk menawarkan pelanggan kopi kualitas tertinggi dan pengalaman kopi terbaik, sementara beroperasi dengan cara yang menghasilkan sosial, lingkungan dan benefit ekonomi bagi masyarakat di mana ia melakukan bisnis. Starbucks memasuki pasar Inggris pada tahun 1998 dan sekarang mempekerjakan lebih dari 11.000 mitra di lebih dari 700 kedai kopi. Munculah ide dari perusahaan Starbucks untuk membuat kopi menjadi minuman yang mewah. Konsep starbucks selain ingin mengangkat nama kopi sebagai minuman mewah, strabucks ingin membuat sebuah konsep tempat berkumpul dengan sahabat, rekan kerja dan membuat kedai kopi sebagai tempat lain selain kantor untuk bekerja. Seperti yang diketahui banyak pekerja kantor yang sering mengadakan pertemuan kantor atau sekedar berkumpul bersama di tempat kedai kopi. Hal tersebut membuat Starbucks menjadi salah satu merek kedai kopi terkenal dan sampai mendunia.

Starbucks Coffee merupakan perusahaan yang bergerak dibidang bisnis Cofee Retail, dimana perusahaan menyediakan hidangan kopi siap minum dengan ragam cara dan rasa yang digiling, dipanggang serta diseduh dari biji-biji kopi terbaik di seluruh dunia. Dengan pesatnya perkembangan industri ini, Starbucks Coffee perlu menerapkan strategi pemasaran yang tepat dalam upaya menghadapi serangan pesaingnya. Salah satu satrategi untuk menunjang kesuksesan pemsarannya adalah dengan strategi Segmenting, Targeting, dan Positioning.

Disamping penerapan strategi yang tepat, Starbucks Coffee juga mampu menganalisa faktor-faktor yang mempengaruhi konsumen untuk memilih dan membeli produk Starbucks dengan akiurat.

Menurut Hermawan Kartajaya (2006:16), Starbucks dengan slogannya "The WorldIs Finest Coffee Experience", Starbucks mampu secara unik memposisikan diri bukan sebagai warung atau restoran kopi yang mengagung-agungkan keenakan kopinya, tetapi lebih sebagai tempat menikmati "pengalaman ngopi". Melalui slogannya, ia ingin 
mengatakan kepada setiap pelanggannya bahwa mereka akan menikmati pengalaman see and to be seen dan bukan sekedar kopi yang enak. Starbucks tidak hanya menyajikan produk kopi bagi pelanggannya, tapi produk jasa berupa kepedulian terhadap kenyamanan pelanggan.

Dengan perkembangan pasar yang potensial dan menjanjikan di Indonesia. Starbucks Coffee Indonesia berniat menambah jumlah gerainya. Starbucks Coffee Indonesia pun mengklaim pertumbuhan sebesar 20 persen. Hal tersebut menggambarkan konsumsi atas produk Starbucks di Indonesia cukup tinggi. Citra sebagai produk untuk kelas menengah keatas bias menjadi kelemahan namun dalam hal ini justru sebaliknya menjadi kekuatan image. Starbucks Indonesia untuk bisa memperluas segmen pasar dan menambah tingkat penjualan. Dapat disimpulkan bahwa selain harga, ada faktor lain yang mempengaruhi konsumen dalam melakukan keputusan pembelian.

Dalam hal memposisikan produk, ternyata Starbucks tidak hanya memposisikan produknya berdasarkan kualitas produk, harga,tempat/lokasi, serta promosi tetapi juga berdasarkan kombinasi keempat faktor tersebut.

Berdasar uraian latar belakang diatas, maka penulis tertarik untuk melakukan penelitian ini bertujuan untuk mengetahui latar belakang apa yang dominan mempengaruhi konsumen dalam pengambilan keputusan pembelian produk starbucks di kota Bogor .

\section{METODOLOGI PENELITIAN}

\section{Tempat Penelitian}

Dalam hal ini penelitian dilakukan di Starbucks CoffeeMall Botani Square Bogor, dengan menyebarkan kuisioner kepada konsumen Starbucks.

\section{Desain Penelitian}

Rangkaian riset yang dilakukan peneliti menggambarkan kegiatan mulai dari hipotesa hingga sampai analisa data. Metode yang digunakan dalam riset ini adalah metode survey yaitu mengambil data dari responden yang telah memberikan informasi dari kuisioner yang telah diberikan secara acak random dari suatu populasi. Jawaban - jawaban dari hasil kuisioner yang telah didapatkan, menjadi sumber data utama. Dengan demikian penelitian ini menjelaskan hubungan sebab akibat antara variabelvariabel penelitian melalui hipotesis yang harus diuji melalui analisa regresi dan korelasi. Obyek penelitian dalam penelitian ini adalah konsumen Starbucks coffee yang memutuskan untuk membeli produk Starbucks Coffee.

\section{Populasi dan Sampel}

Populasi adalah serumpun atau sekelompok objek yang menjadi sasaran penelitian yang mempunyai sejumlah karakteristik umum.

Populasi yang dimaksud dalam penelitian ini adalah konsumen Starbucks Coffee yang pernah membeli, menikmati produk starbucks serta berada di dalam Starbucks Coffee.

Sampel merupakan bagian dari populasi yang ingin diteliti, dipandang sebagai suatu pendugaan terhadap populasi, namun bukan populasi itu sendiri. Sampel dianggap sebagai perwakilan dari populasi yang hasilnya mewakili keseluruhan gejala yang diamati.

$\mathrm{n}=\frac{\mathrm{Z}^{2}}{4 \mu^{2}}$

dimana :

$\mathrm{n}=$ ukuran sampel

$\mathrm{Z}$ = tingkat keyakinan sampel yang dibutuhkan

dalam penelitian pada obyek, pada $\alpha=5 \%$ (derajat

keyakinan ditentukan 95\%) maka $\mathrm{Z}=1,96$

$\mu=$ margin of error, tingkat kesalahan yang ditolerir

(ditentukan 10\%)

$\mathrm{n}=\underline{1,96^{2}}$

$4(0,1)^{2}$

$\mathrm{n}=96,4 \approx 100$

\section{Teknik Pengumpulan Data}

Sampel yang baik mengandung dua kriteria (Supranto, J, 1997) yang pertama adalah cermat dan akurat yaitu sampel yang diambil tidak akan liar, dimana sampel tersebut tidak akan memberikan reaksi yang terlalu berlebihan yang dapat mewakili populasi secara wajar. Kriteria kedua adalah tepat (precetion) yaitu sampel yang diambil dapat meneliti populasi secara wajar dengan hanya meneliti sampel yang tepat dan sesuai dengan pertimbangan tujuan penelitian.

Gunamendapatkan data utama yang dibutuhkan, cara yang dilakukan adalah dengan wawancara (interview), angket (kuisioner) dan pengamatan (observasi) dan kombinasi ketiganya. Untuk mendapatkan data sekunder bisa dengan riset arsip dan studi pustaka. Metode pengumpulan data yang digunakan dalam riset ini adalah:

\section{Kuisioner}

Dalam riset ini data didapatkan dengan cara tatap muka dengan responden baik secara langsung maupun tidak langsung dan responden memberikan jawaban - jawaban atas pertanyaan - pertanyaan diajukan di dalam kuisioner.

\section{Dokumentasi}

Guna memperoleh data-data sekunder sebagai data pendukung, maka dilakukan penelitian terhadap arsip maupun dokumen yang dibutuhkan, seperti data dari media massa baik dari media cetak maupun media elektronika. 


\section{Instrumen Penelitian}

Dalam penelitian ini ada dua variabel, yang terdiri dari variabel terikat (dependent variable) dan variabel bebas (independent variable). Variabel bebas yaitu variabel yang bisa mempengaruhi perubahan dalam variabel terikat dan mempunyai pengaruh dengan variabel terikat lainnya. Variabel bebas dalam riset ini adalah terdiri dari : Produk, harga, tempat dan promosi. Sedangkan variabel terikat merupakan variabel yang hasilnya atau nilainya selalu dipengaruhi oleh variabel bebas. Variabel terikat dalam hal ini adalah variabel yang menjadi perhatian utama dalam sebuah penelitian. Variabel terikat dalam riset ini adalah keputusan konsumen dalam pembelian produk Starbucks.

Pada penelitian ini, analisis deskriptif dilakukan dengan cara memberi pembobotan/skor pada setiap alternatif jawaban. Pembobotan dilakukan dengan menggunakan skala Likert yang terdiri lima poin sebagai berikut :

Apabila jawabannya adalah sangat tidak baik diberi skor 1

Apabila jawabannya adalah tidak baik diberi skor 2 Apabila jawabannya adalah cukup baik diberi skor 3 Apabila jawabannya adalah baik diberi skor 4 Apabila jawabannya adalah sangat baik diberi skor 5

\section{Tabel 1.Definisi Operasional Variabel}

\begin{tabular}{|c|c|c|}
\hline Variabel & Indikator & Skala \\
\hline Produk & $\begin{array}{l}\text { Merk } \\
\text { Pengemasan } \\
\text { Kualitas } \\
\text { Kuantitas } \\
\text { Variasi menu } \\
\text { Higienitas } \\
\end{array}$ & $\begin{array}{l}\text { Likert } \\
\text { Likert } \\
\text { Likert } \\
\text { Likert } \\
\text { Likert } \\
\text { Likert }\end{array}$ \\
\hline Harga & $\begin{array}{l}\text { Daftar harga } \\
\text { Diskon } \\
\text { Kredit }\end{array}$ & $\begin{array}{l}\text { Likert } \\
\text { Likert } \\
\text { Likert }\end{array}$ \\
\hline Tempat & $\begin{array}{l}\text { Lingkungan masyarakat } \\
\text { Kedekatan dengan pasar I } \\
\text { Dekat dengan supplier } \\
\text { Fasilitas transportasi }\end{array}$ & $\begin{array}{l}\text { Likert } \\
\text { Likert } \\
\text { Likert } \\
\text { Likert }\end{array}$ \\
\hline Promosi & $\begin{array}{l}\text { Iklan merk di media } \\
\text { Image / citra status sosial } \\
\text { Prestise kebanggaan }\end{array}$ & $\begin{array}{l}\text { Likert } \\
\text { Likert } \\
\text { Likert }\end{array}$ \\
\hline $\begin{array}{l}\text { Keputusan } \\
\text { Pembelian }\end{array}$ & $\begin{array}{l}\text { Keyakinan membeli } \\
\text { Rekomendasi } \\
\text { Kebiasaan } \\
\text { Pembelian ulang }\end{array}$ & $\begin{array}{l}\text { Likert } \\
\text { Likert } \\
\text { Likert } \\
\text { Likert }\end{array}$ \\
\hline
\end{tabular}

Sumber : (Kotler, 2007)

\section{Kerangka Berpikir Dan Hipotesis}

Di dalam penelitian ini, ada 4 faktor yang mempengaruhi konsumen dalam pengambilan keputusan pembelian produk Starbucks. Penelitian ini dilakukan dengan memberikan kuisioner kepada konsumen Starbucks yang telah membeli produk produk Starbucks di Starbucks Coffee. Untuk melihat gambaran yang lebih jelas, maka disusunlah kerangka pemikiran seperti gambar sebagai berikut :

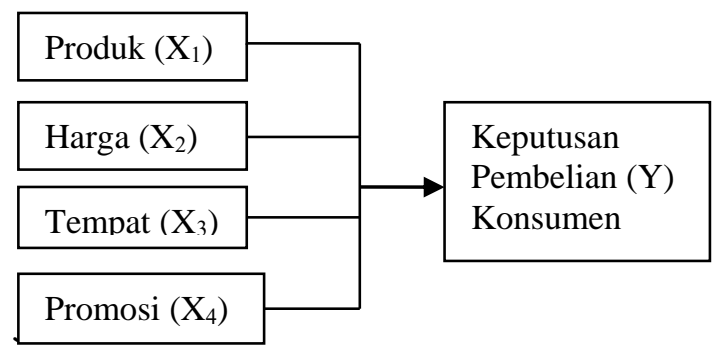

Gambar 1. Kerangka Pemikiran

Hipotesis merupakan jawaban sementara terhadap rumusan masalah penelitian (Sugiyono, 2010: 93). Dengan mengacu pada rumusan masalah, landasan teori, dan kerangka pemikiran tersebut, maka hipotesis yang diajukan penelitian ini adalah :

Bahwa faktor Produk ( Product), Harga (Price), tempat (Place) dan promosi (promotion) merupakan faktor yang mempengaruhi konsumen dan memiliki pengaruh positif terhadap keputusan pembelian.

$\mathrm{H}_{1}=$ Diduga terdapat pengaruh antara faktor produk dengan keputusan pembelian.

$\mathrm{H}_{2}=$ Diduga terdapat pengaruh antara faktor harga dengan keputusan pembelian.

$\mathrm{H}_{3}=$ Diduga terdapat pengaruh antara faktor tempat dengan keputusan pembelian.

$\mathrm{H}_{4}=$ Diduga terdapat pengaruh antara faktor promosi dengan keputusan pembelian.

\section{Penelitian Terdahulu}

Penelitian (Komalasari F, 2013) meneliti tentang pengaruh bauran pemasaran terhadap pengaruh keputusan keputusan konsumen untuk membeli di , hasil penelitian ini hanya 4 variabel yang berpengaruh signifikan, yaitu produk, promosi, harga dan tempat baik secara parsial dan simultan. Sedangkan faktor yang berpengaruh dominan terhadap pengambilan keputusan pembelian di adalah harga dan distribusi.

Penelitian (Melisa, Yuda, 2012) meneliti tentang pengaruh bauran pemasaran ritel terhadap keputusan pembelian ulang konsumen di dalam penelitian ini menunjukan bahwa, bauran pemasaran ritel yang terdiri dari persediaan barang, harga, lokasi, bauran komunikasi, desain dan tampilan toko berpengaruh signifikan terhadap keputusan pembelian ulang konsumen.

Penelitian (Masrita, 2013) meneliti tentang sebarapa besar pengaruh bauran pemasaran terhadap keputusan pembelian baik secara parsial maupun secara simultan dan manakah dari keempat variabel 
bauran pemasaranyang paling berpengaruh terhadap keputusan pembelian. Hasil penelitian menunjukkan bahwa bauran pemasaran yang terdiri dari produk, harga, distribusi/tempat, dan promosi secara simultan berpengaruh terhadap keputusan pembelian. Secara parsial, hanya harga dan tempat merupakan variable yang paling berpengaruh dan mampu mempengaruhi konsumen untuk membuat keputusan membeli suatu produk.

\section{HASIL DAN PEMBAHASAN}

Pada bagian ini akan dijelaskan hasil penelitian yang telah dilakukan tentang faktor-faktor bauran pemasaran yang mempengaruhi keputusan pembelian konsumen Starbucks. Data-data didapatkan dengan cara memberikan kuisioner kepada para konsumen Starbucks yang pada saat berada di Starbucks Coffee maupun di tempat lain. Data-data yangtelah diperoleh kemudian dilakukan uji validitas dan reliabilitas. Uji validitas maupun reliabilitas itu bertujuan untuk mengetahui apakah data-data yang akan menjadi instrumen itu valid dan reliabel.

Tabel 2.

\section{Hasil Uji Validitas}

\begin{tabular}{|c|c|c|c|c|c|}
\hline $\begin{array}{l}\text { Variab } \\
\text { el }\end{array}$ & $\begin{array}{l}\text { Item/Ko } \\
\text { de }\end{array}$ & $\begin{array}{l}\text { Korel } \\
\text { asi } \\
\text { Bivari } \\
\text { at }\end{array}$ & $\begin{array}{l}\text { Correcte } \\
\text { d Item - } \\
\text { Total } \\
\text { Correlati } \\
\text { on } \\
\end{array}$ & $\begin{array}{c}\mathbf{r} \\
\text { Tab } \\
\text { el }\end{array}$ & $\begin{array}{l}\text { Keterang } \\
\text { an }\end{array}$ \\
\hline \multirow{6}{*}{ Produk } & & & 0.331 & 0.19 & Valid \\
\hline & X1.1 & 0.703 & & 5 & \\
\hline & & & 0.494 & 0.19 & Valid \\
\hline & $\mathrm{X} 1.2$ & 0.797 & & 5 & \\
\hline & & & 0.417 & 0.19 & Valid \\
\hline & X1.3 & 0.741 & & 5 & \\
\hline \multirow{3}{*}{ Harga } & $\mathrm{X} 2.1$ & 0.753 & 0.399 & $\begin{array}{c}0.19 \\
5\end{array}$ & Valid \\
\hline & $\mathrm{X} 2.2$ & 0.771 & 0.519 & $\begin{array}{c}0.19 \\
5\end{array}$ & Valid \\
\hline & $\mathrm{X} 2.3$ & 0.802 & 0.518 & $\begin{array}{c}0.19 \\
5\end{array}$ & Valid \\
\hline \multirow{3}{*}{ Tempat } & X3.1 & 0.813 & 0.591 & $\begin{array}{c}0.19 \\
5\end{array}$ & Valid \\
\hline & X3.2 & 0.712 & 0.277 & $\begin{array}{c}0.19 \\
5\end{array}$ & Valid \\
\hline & X3.3 & 0.736 & 0.403 & $\begin{array}{c}0.19 \\
5\end{array}$ & Valid \\
\hline \multirow{3}{*}{ Promosi } & $\mathrm{X} 4.1$ & 0.774 & 0.525 & $\begin{array}{c}0.19 \\
5\end{array}$ & Valid \\
\hline & $\mathrm{X} 4.2$ & 0.861 & 0.668 & $\begin{array}{c}0.19 \\
5\end{array}$ & Valid \\
\hline & $\mathrm{X} 4.3$ & 0.890 & 0.731 & $\begin{array}{c}0.19 \\
5\end{array}$ & Valid \\
\hline \multirow{4}{*}{$\begin{array}{l}\text { Keputus } \\
\text { an }\end{array}$} & Y.1 & 0.699 & 0.497 & $\begin{array}{c}0.19 \\
5\end{array}$ & Valid \\
\hline & Y.2 & 0.772 & 0.531 & $\begin{array}{c}0.19 \\
5\end{array}$ & Valid \\
\hline & Y.3 & 0.749 & 0.556 & $\begin{array}{c}0.19 \\
5\end{array}$ & Valid \\
\hline & Y.4 & 0.789 & 0.578 & $\begin{array}{c}0.19 \\
5\end{array}$ & Valid \\
\hline
\end{tabular}

valid dengan t-hitung > t-tabel. Dengan hasil uji ini menunjukan bahwa, bahwa data yang akan diteliti tidak ada masalah dan memenuhi syarat untuk dianalisis dalam analisa regresi.

Suatu angket kuesioner dinyatakan reliabel apabila jawaban terhadap responden terhadap pernyataan adalah konsisten/ stabil di waktu ke waktu. Teknik yang digunakan untuk mengukur tingkat reliabilitas adalah Cronbach Alpha dengan cara membandingkan nilai Alpha dengan standarnya.

Tabel 3

\section{Hasil Uji Reliabilitas}

\begin{tabular}{lccc}
\hline Variabel & $\begin{array}{c}\text { Cronbac } \\
\text { h Alpha }\end{array}$ & $\begin{array}{c}\text { Standar } \\
\text { Reliabilita } \\
\text { s }\end{array}$ & $\begin{array}{c}\text { Keteranga } \\
\text { n }\end{array}$ \\
\hline Produk & 0.603 & 0.60 & Reliabel \\
\hline Harga & 0.662 & 0.60 & Reliabel \\
\hline Tempat & 0.598 & 0.60 & Reliabel \\
\hline Promosi & 0.795 & 0.60 & Reliabel \\
\hline $\begin{array}{l}\text { Keputusa } \\
\mathrm{n}\end{array}$ & 0.743 & 0.60 & Reliabel
\end{tabular}

Sumber:Hasil pengolahan data kuesioner, 2017

Hasil nilai cronbachs alpha variabel produk, harga, tempat, promosi dan keputusan pembelian > 0,60 sehingga indikator atau kuesioner dari keenam variabel tersebut reliabel atau layak dipercaya sebagai alat ukur variabel.

Namun, untuk nilai cronbachs alpha variabel atribut produk $<0,60$ sehingga indikator atau kuesioner dari variabel tersebut dinyatakan cukup reliabel atau cukup layak dipercaya sebagai alat ukur variabel.

Analisis regresi berganda digunakan untuk mengetahui pengaruh antara variabel independen terhadap variabel dependen, sekaligus untuk melihat hasil pengujian hipotesis yang diajukan. Hasil regresi antara bauran pemasaran yang meliputi produk, harga, tempat, promosi, orang, proses dan fisik terhadap keputusan pembelian produk Starbucks di kota Bogor dapat dilihat hasilnya sebagai berikut.

Tabel 4

Hasil Regresi Coefficientsa

\begin{tabular}{cccc}
\hline Model & $\begin{array}{c}\text { Unstandardized } \\
\text { Coefficients }\end{array}$ & & $\begin{array}{c}\text { Standardized } \\
\text { Coefficients }\end{array}$ \\
\hline & $\mathrm{B}$ & $\begin{array}{c}\text { Std. } \\
\text { error }\end{array}$ & Beta \\
\hline $\begin{array}{c}\text { (Constant) } \\
\mathrm{X} 1\end{array}$ & -1.518 & 1.330 & \\
\hline $\mathrm{X} 2$ & .532 & .108 & .381 \\
\hline
\end{tabular}


Faktor Bauran Pemasaran Yang Mempengaruhi Konsumen Terhadap Keputusan Pembelian Produk Pada Konsumen Starbucks Coffee

\begin{tabular}{cccc}
\hline $\mathrm{X} 3$ & .350 & .110 & .268 \\
\hline $\mathrm{X} 4$ & -.125 & .178 & -.113 \\
\hline
\end{tabular}

a. Dependent Variable: Y

Dari tabel diatas dapat diperoleh persamaan regresi linear berganda sebagai berikut:

$Y=0,381 X_{1}+0,157 X_{2}+0,268 X_{3}+\left(-0.113 X_{4}\right)$

b1 $=0,381$; artinya apabila kenaikan variabel $X_{2}, X_{3}$ $\mathrm{X}_{4}=$ konstan, maka kenaikan variabel produk $\left(\mathrm{X}_{1}\right)$ sebesar 1 satuan akan menyebabkan kenaikan variabel keputusan pembelian (Y) sebesar $\mathbf{0 , 5 3 2}$.

b2 $=\mathbf{0 , 1 5 7}$; artinya apabila kenaikan variabel $X_{1}, X_{3}$ $\mathrm{X}_{4}=$ konstan, maka kenaikan variabel harga $\left(\mathrm{X}_{2}\right)$ sebesar 1 satuan akan menyebabkan kenaikan variabel keputusan pembelian (Y) sebesar $\mathbf{0 , 1 8 8}$.

b3 = 0,268; artinya apabila kenaikan variabel $\mathrm{X}_{1} \mathrm{X}_{2}$ $\mathrm{X}_{4}=$ konstan, maka kenaikan variabel tempat $\left(\mathrm{X}_{3}\right)$ sebesar 1 satuan akan menyebabkan penurunan variabel keputusan pembelian (Y) sebesar $\mathbf{0 , 3 5 0 .}$

b4 = -0,113; artinya apabila kenaikan variabel $X_{1}$, $\mathrm{X}_{2} \quad \mathrm{X}_{3}=$ konstan, maka kenaikan variabel promosi $\left(\mathrm{X}_{4}\right)$ sebesar 1 satuan akan menyebabkan kenaikan variabel keputusan pembelian (Y) sebesar -0,125.

Uji koefisien determinasi $\left(\mathrm{R}^{2}\right)$ digunakan untuk mengukur seberapa jauh kemampuan model dalam menerangkan variasi variabel dependen (Ghozali dalam Hardian 2010: 121). Nilai $\mathrm{R}_{2}$ yang semakin mendekati 1 , berarti variabel-variabel independen memberikan hampir semua informasi yang dibutuhkan untuk memprediksi variasi variabel independen. Koefisien determinasi yang digunakan adalah Adjusted $R$ Square karena lebih dapat dipercaya dalam mengevaluasi model regresi. Nilai Adjusted $R$ Squaredapat naik atau turun apabila satu variabel ditambahkan kedalam model. Berbeda dengan $R$ Square yang pasti akan meningkat setiap tambahan satu variabel independen, tidak peduli apakah variabel tersebut berpengaruh secara signifikan terhadap variabel dependen.

\section{Tabel 6}

\section{Hasil Koefisien Determinasi $\left(\mathbf{R}^{2}\right)$}

Model Summary ${ }^{\mathrm{b}}$

\begin{tabular}{|c|c|c|c|c|}
\hline Model & $\mathrm{R}$ & $\begin{array}{l}\mathrm{R} \\
\text { Square }\end{array}$ & $\begin{array}{l}\text { Adjusted } \\
\text { R } \\
\text { Square }\end{array}$ & $\begin{array}{c}\text { Std. } \\
\text { Error } \\
\text { of the } \\
\text { Estimate }\end{array}$ \\
\hline 1 & $.829^{\mathrm{a}}$ & .687 & .663 & 1.425 \\
\hline
\end{tabular}

Dari hasil analisis faktor-faktor yang mempengaruhi keputusanpembelian pada tabel 5.14 menunjukkan nilai adjusted $\mathrm{R}_{2}$ sebesar 0.663 , hal ini berarti seluruh variabel turunan bauran pemasaran mempunyai kontribusi secara bersama-sama sebesar $66,3 \%$ terhadap variabel terikat $(\mathrm{Y})$ yakni keputusan pembelian. Sisanya sebesar $33,7 \%$ dipengaruhi oleh faktor-faktor lain yang tidak masuk dalam penelitian.

Standard Error of The Estimate (SEE) dari tabel diatas sebesar1,425. Semakin kecil nilai SEE, maka akan membuat persamaan regresi semakin tepat dalam memprediksi variabel dependen.

Uji serempak atau uji $F$ merupakan uji secara bersama-sama untuk menguji signifikansi pengaruh variabel Produk $\left(\mathrm{X}_{1}\right)$, Harga $\left(\mathrm{X}_{2}\right)$, Tempat $\left(\mathrm{X}_{3}\right)$, Promosi $\left(\mathrm{X}_{4}\right)$, dan kemudahan penggunaan secara bersama-sama terhadap variabel keputusan pembelian (Y). Uji $\mathrm{F}$ dilakukan dengan membandingkan $\mathrm{F}$ hitung dengan $\mathrm{F}$ tabel.

Tabel 6

Hasil Uji Simultan F

\section{ANOVA $^{b}$}

\begin{tabular}{llclll}
\multicolumn{6}{c}{ ANOVA $^{\mathrm{a}}$} \\
\hline Model & $\begin{array}{l}\text { Sum of } \\
\text { Squares }\end{array}$ & df & $\begin{array}{l}\text { Mean } \\
\text { Square }\end{array}$ & F & Sig. \\
\hline 1Regression & 409.266 & 7 & 58.467 & 28.788 & $.000^{\mathrm{b}}$ \\
Residual & 186.844 & 92 & 2.031 & & \\
Total & 596.110 & 99 & & & \\
\hline
\end{tabular}

a. Dependent Variable: Y

b. Predictors: (Constant), $\mathrm{X}_{1}, \mathrm{X}_{3}, \mathrm{X}_{2}, \mathrm{X}_{4}$

Sumber :Hasil pengolahan data kuesioner, 2017

Berdasarkan hasil uji simultan dari tabel 4.17 ditunjukkan bahwa $\mathrm{F}_{\text {hitung }}$ sebesar 28,778, sedangkan hasil $\mathrm{F}_{\text {tabel }}$ pada tabel distribusi dengan tingkat kesalahan 5\% adalah sebesar 2,18. Hal ini berarti $F_{\text {hitung }}>F_{\text {tabel }}(28,778>2,18)$. Nilai signifikansi lebih kecil dari 0,05. Perhitungan tersebut menunjukkan bahwa seluruh variabel turunan bauran pemasaran (X) secara bersama-sama mempunyai pengaruh yang positif dan signifikan terhadap variabel keputusan pembelian (Y).

Pengujian ini untuk melihat sejauh mana pengaruh secara terpisah dari masing-masing variabel bebas (X) terhadap variabel terikat (Y) berdasarkan hasil regresi yang ada pada tabel 5 uji t dilakukan dengan membandingkan nilai t hitung dengan t tabel dengan tingkat kesalahan 5\% yakni 1,660. Apabila t hitung $>\mathrm{t}$ tabel maka dapat disimpulkan variabel tersebut mempunyai pengaruh yang signifikan. 
Variabel Produk $\left(X_{l}\right)$

Nilai thitung untuk variabel ini sebesar 4,941. Sementara itu nilai pada tabel distribusi $5 \%$ sebesar 1,660. Maka thitung $(4,941)>_{\text {ttabel }}(1,660)$ dan nilai signifikansi $(0,000<0,532)$ artinya variabel $\operatorname{produk}\left(\mathrm{X}_{1}\right)$ berpengaruh positif dan signifikan terhadap keputusan pembelian.

Starbuck mengimplentasikan dengan menerapkan standar mutu tinggi baik bahan baku produk maupun proses pengolahannya, sehingga kualitas produknya tetap terjaga dengan baik.

\section{Variabel Harga $\left(X_{2}\right)$}

Nilai thitung untuk variabel ini sebesar 1,743. Sementara itu nilai pada tabel distribusi $5 \%$ sebesar 1,660. Maka thitung $(1,743)>_{\text {ttabel }}(1,660)$ dan nilai signifikansi $(0,085<0,188)$ artinya variabel harga $\left(\mathrm{X}_{2}\right)$ berpengaruh positif dan signifikan terhadap keputusan pembelian.

Starbucks memberikan kemudahan dalam pembayaran kepada konsumen, baik pembayaran tunai maupun non tunai

Variabel tempat $\left(X_{3}\right)$

Nilai thitung untuk variabel ini sebesar 3,192. Sementara itu nilai pada tabel distribusi $5 \%$ sebesar 1,660.Makathitung 3,192 $>_{\text {ttabel }}$ (1,660dan nilai signifikansi $(0.002<0,350)$ artinya variabel tempat $\left(\mathrm{X}_{3}\right)$ berpengaruh positif dan signifikan terhadap keputusan pembelian.

Starbucks berada di lokasi strategis yang mudah dijangkau baik oleh konsumen maupun suplier

\section{Variabel promosi $\left(X_{4}\right)$}

Nilai thitung untuk variabel ini sebesar $-0,703$. Sementara itu nilai pada tabel distribusi $5 \%$ sebesar 1,660. Maka thitung $(-0,703)<_{\text {ttabel }}(1,660)$ dan nilai signifikansi $0,484>(-0,125)$ artinya variabel promosi $\left(\mathrm{X}_{4}\right)$ berpengaruh negatif tetapi tidak signifikan terhadap keputusan pembelian.

Starbuck melaksanakan pemasangan papan nama sebagai tanda keberadaan Starbucs di tempat tertentu.

Namun demikian dalam penelitian ini masih ada kelemahan yaitu responden yang homogen dengan berbagai tingkat kunjungan yang beragam di Starbucks Coffee, sehingga tingkat pemahaman pada konsumen yang di survey itu ada yang mengerti secara mendalam dan ada yang kurang tentang produk Starbucks beserta pelayanannya. Hal ini bisa mengurangi tingkat keakuratan dalam output yang dihasilkan dari suatu penelitian.

\section{KESIMPULAN}

Berdasarkan hasil analisis dan pembahasan yang telah dilakukan, maka dapat ditarik kesimpulan sebagai berikut :

Variabel produk $\left(\mathrm{X}_{1}\right)$ adalah variabel yang paling dominan berpengaruh terhadap keputusan pembelian. Apabila Starbucks meningkatkan strategi bauran pemasarannya dan dapat memberikan diferensiasi produk yang menarik daripada pesaingnya, konsumen akan semakin menyimpan Starbucks dalam memory mereka karena diferensiasi tersebut.

Berdasarkan nilai koefisien determinasi menunjukkan nilai adjusted R2 sebesar 0,663 hal ini berarti seluruh variabel turunan strategi marketing mix mempunyai kontribusi secara bersama-sama sebesar $66,3 \%$ terhadap variabel terikat (Y) yakni keputusan pembelian. Sisanya sebesar 33,7\% dipengaruhi oleh faktor-faktor lain yang tidak masuk dalam penelitian.

Berdasarkan perhitungan Uji Simultan F dengan nilai $\mathrm{F}=28,778$ dimana nilai tersebut lebih besar daripada nilai $\mathrm{F}$ tabel $(2,18)$ dan nilai signifikan 0,000 lebih kecil dari nilai probabilitas 0,05 maka seluruh variabel turunan strategi bauran pemasaran (X) secara bersama-sama mempunyai pengaruh yang positif dan signifikan terhadap variabel keputusan pembelian (Y).

\section{REFERENSI}

Kartajaya, Hermawan, 2006, Hermawan Kartajaya on Positioning, Bandung : Mizan

Kartajaya, Hermawan, 2008, Newwave Marketing, Jakarta : Gramedia Pustaka Utama

Komalasari, F. (2012). Pengaruh Bauran Pemasaran Terhadap keputusan Pembelian Produk Handphone Nokia Eseries. Jurnal Manajemen, (100), 1-13.

Kotler, Amstrong, 2006, Manajemen Pemasaran, Jakarta : PT. Prehalindo

Melisa, Y. (2012). Pengaruh Bauran Pemasaran Ritel Terhadap Keputusan Pembelian Ulang Konsumen Mega Prima Swalayan Payakumbuh. Junal Manajemen.

Masrita. (2013). Pengaruh Bauran Pemasaran Terhadap Keputusan Pembelian Batik Jambi. Jurnal DinamikaManajemen, 1(3), 198-215. 
Faktor Bauran Pemasaran Yang Mempengaruhi Konsumen Terhadap Keputusan Pembelian Produk Pada Konsumen Starbucks Coffee

Novita Klarisa. (2013). Pengaruh Bauran Promosi Terhadap Keputusan Pembelian Konsumen Di Swalayan Maxi Balikpapan. Jurnal Manajemen, 1-15.

Supranto, J. (1997).Pengukuran Tingkat Kepuasan Pelanggan, Jakarta : PT. Gramedia Pustaka Utama

Sugiyono, 2010, Metode Penelitian Pendidikan Pendidikan Kuantitatif, Kualitatif, dan R \& D, Bandung, Alfa Beta.
Suprapti, Lilik, 2010, Analisis Pengaruh Brand Awareness, Perceived Value, Organizational Assocation dan Perceived Quality Terhadap Keputusan Pembelian Konsumen. Jurnal Riset Pemasaran

\section{PROFIL PENULIS}

Arief Satriansyah, saat ini aktif mengajar di Universitas Bina Sarana Informatika Jakarta dengan konsentrasi Manajemen spesial manajemen pemasaran. 